\title{
Faktor penentu indeks pembangunan manusia dan hubungannya dengan belanja infrastruktur serta pertumbuhan ekonomi Kabupaten/Kota Provinsi Jambi
}

\author{
Herinoto*; M. Rachmad R; Zulfanetti \\ Prodi Magister Ilmu Ekonomi, Program Pascasarjana, Universitas Jambi \\ *E-mail korespodensi: herimozi@gmail.com
}

\begin{abstract}
This study aims to analyze the factors that determine the Human Development Index (HDI), to analyze the relationship between HDI and infrastructure spending, and to analyze the relationship between infrastructure spending and economic growth in districts/cities in Jambi Province. The data used in this study are secondary data with the type of Time Series 2012-2018 and Cross Section 11 districts/cities. This study uses Panel Data Multiple Regression Analysis and Simple Correlation Analysis using the E-views 10 tool. The results of this study indicate that the HDI of districts/cities in Jambi Province increases every year, partially the ratio of teachers to students, number of health facilities, and density. The population has a positive and significant effect in determining HDI. While the poverty factor has a negative but not statistically significant effect in determining the HDI of districts/cities in Jambi Province with an R-Square value of 0.9312. The relationship between HDI and infrastructure spending has a negative and insignificant effect, which means that an increase in infrastructure spending will increase the decrease in the value of HDI. The relationship between growth spending and economic growth has a positive and significant effect, which means that an increase in the value of infrastructure spending will increase the value of economic growth.
\end{abstract}

Keywords: Human development index, Infrastructure spending, Economic growth

\begin{abstract}
Abstrak
penelitian ini bertujuan untuk menganalisis faktor-faktor yang menentukan Indeks Pembangunan Manusia (IPM), untuk menganalisis hubungan antara IPM dengan belanja infrastruktur dan untuk menganalisis hubungan antara belanja infrastruktur dengan pertumbuhan ekonomi kabupaten/kota di Provinsi Jambi. Data yang digunakan dalam penelitian ini adalah data sekunder dengan jenis data Time Series 2012-2018 dan Cross Section 11 kabupaten/kota. Penelitian ini menggunakan analisis regresi berganda data panel dan analisis korelasi sederhana dengan menggunakan alat E-views 10. Hasil dari penelitian ini menunjukkan bahwa IPM kabupaten/kota di Provinsi Jambi meningkat setiap tahunnya, secara parsial Ratio Guru dan Murid, Jumlah Sarana Kesehatan, dan Kepadatan Penduduk berpengaruh positif dan signifikan dalam menentukan IPM. Sedangkan faktor Kemiskinan berpengaruh negatif tetapi tidak signifikan secara statistik dalam menentukan IPM kabupaten/kota di Provinsi Jambi dengan nilai R-Square sebesar 0.9312. Hubungan antara IPM dengan belanja infrastruktur berpengaruh negatif dan tidak signifikan yang berarti semakin naik belanja infrastruktur maka akan semakin menurunkan nilai IPM. Hubungan antara belanja infrastruktur dengan pertumbuhan ekonomi berpengaruh positif dan signifikan yang berarti semakin naik nilai belanja infrastruktur maka akan semakin menaikkan nilai pertumbuhan ekonomi.
\end{abstract}

Kata kunci: Indeks pembangunan manusia, Belanja infrastruktur, Pertumbuhan ekonomi 


\section{PENDAHULUAN}

Pada dasarnya Indonesia sudah menganut konsep Indeks Pembangunan Manusia (IPM) yang diatur dalam Undang-undang No. 17 tahun 2007 tentang Rencana Pembangunan Jangka Panjang (RPJP) Nasional Tahun 2005-2025, yang menyatakan bahwa pendidikan bersama-sama dengan kesehatan dan peningkatan daya beli keluarga/masyarakat adalah tiga pilar utama untuk meningkatkan kualitas Sumber Daya Manusia (SDM) dan Indeks Pembangunan Manusia (IPM). Indeks Pembangunan Manusia merupakan indikator penting untuk mengukur keberhasilan dalam upaya membangun kualitas hidup manusia yang mencakup tiga dimensi dasar yaitu dimensi sosial, kesehatan, dan ekonomi. Dimensi sosial perwujudannya adalah tingkat pengetahuan dengan indikator Harapan Lama Sekolah (HLS) dan Rata-Rata Lama Sekolah (RLS). Dimensi kesehatan perwujudannya adalah umur panjang dan sehat dengan indikator Angka Harapan Hidup (AHH) saat lahir. Dimensi ekonomi perwujudannya adalah kehidupan yang layak diukur dengan indikator pengeluaran perkapita riil yang disesuaikan (Purchasing Power Parity) atau daya beli (BPS, 2018).

Laporan Pembangunan Manusia 2014 berjudul "Sustaining Human Progress : Reducing Vulnerabilities and Building Resilience", yang dirilis oleh United Nations Development Programe (UNDP) secara komprehensif menjelaskan kinerja negara-negara dalam menjaga kesejahteraan warganya. Peringkat IPM Indonesia pada tahun 2014 tidak berubah dibandingkan tahun sebelumnya yaitu pada posisi 108. Dilihat dari sudut pandang nasional IPM Indonesia justru menunjukkan peningkatan, namun peningkatan tersebut masih dalam jumlah yang sangat kecil yaitu rata- rata 0,59 per tahun atau sekitar 0,89 persen per tahun. Keadaan yang hampir serupa juga terjadi pada tingkat provinsi. Dimana masing-masing provinsi mengalami peningkatan dalam IPM, namun tidak ada peningkatan IPM yang cukup berarti dari tahun ke tahun. Data Badan Pusat Statistik (BPS) menunjukkan bahwa kondisi IPM pada masing-masing provinsi di Indonesia semenjak tahun 2014-2018 mengalami kenaikan dengan rata-rata kenaikan sebesar 0,6 per tahun. IPM tingkat kabupaten/kota secara umum meningkat namun dalam jumlah yang kurang menggembirakan yaitu rata-rata 0,62 per tahun.

Status otonomi yang dimiliki daerah seharusnya menjadikan pemerintah daerah memiliki kewenangan untuk mengatur sendiri daerahnya dan menjadikan pembangunan dapat berjalan dengan lebih cepat. Otonomi daerah diharapkan lebih mendekatkan pelayanan pemerintah kepada masyarakat, memudahkan masyarakat untuk memonitor dan mengontrol pengelolaan Anggaran Pendapatan dan Belanja Daerah (APBD), serta menciptakan persaingan yang sehat antar daerah dan mendorong timbulnya inovasi.

Alokasi APBD menjadi salah satu cerminan arah kebijakan yang diambil oleh kepala daerah. Prioritas pembangunan suatu daerah pada kurun waktu tertentu dapat dilihat melalui alokasi APBD. Namun, ketidaksesuaian antara jumlah APBD dengan IPM masih sering terjadi di beberapa daerah. APBD yang tinggi seharusnya menunjukkan bahwa daerah tersebut semakin kaya akan sumber daya. Semakin besar kemampuan daerah untuk meningkatkan kesejahteraan masyarakat ditunjukkan dengan angka IPM yang semakin meningkat. Namun pada kenyataannya, hal tersebut tidak selalu terjadi. Rata-rata persentase kenaikan pendapatan daerah di tingkat provinsi pada tahun 20122013 sebesar 17,8 persen sangat jauh dibandingkan dengan persentase kenaikan IPM tahun 2013-2014 sebesar 0,76 persen (BPS, 2015).

Beberapa faktor yang mendukung dilakukannya penelitian ini, salah satunya adalah terkait kewajiban pemerintah untuk meningkatkan kualitas hidup penduduk, dimulai dengan mencukupi kebutuhan dasar, yaitu sandang, pangan, papan, pendidikan dan kesehatan. Namun kenyataanya, besaran anggaran yang dialokasikan untuk kesehatan di beberapa daerah relatif kecil bahkan di bawah besaran minimal yang ditetapkan dalam 
undang-undang termasuk Provinsi Jambi dan beberapa kabupaten/kota di Provinsi Jambi. Menurut Undang-Undang Nomor 36 Tahun 2009 tentang Kesehatan, besaran anggaran untuk urusan kesehatan di daerah sebesar 10 persen dari total APBD di luar gaji. Sampai dengan tahun 2014, masih banyak daerah yang belum dapat memenuhi ketentuan undangundang tersebut termasuk Provinsi Jambi.

Provinsi Jambi merupakan salah satu daerah di Indonesia yang harus berupaya meningkatkan kualitas sumber daya manusianya karena secara geografis letak Provinsi Jambi sangat strategis dalam kawasan ASEAN dan Interregional Sumatera (Provinsi Sumatera Selatan, Sumatera Barat, Riau, Kepulauan Riau, Lampung, Kepulauan Bangka Belitung, dan Bengkulu) sehingga dapat menjadi pintu gerbang keluar dan masuknya barang, jasa dan orang dari Batam, Malaysia dan Singapura serta provinsi lain. Peran Provinsi Jambi kedepan akan semakin strategis sejalan dengan dimulainya pasar bebas ASEAN (AFTA) dan ASEAN-China (ACFTA) (Laporan Keuangan Pemerintah Daerah Provinsi Jambi TA, 2016).

Laju pertumbuhan ekonomi Provinsi Jambi beberapa tahun terakhir tergolong cukup tinggi dan terus menunjukkan tren meningkat, bahkan diatas laju pertumbuhan ekonomi nasional. Namun jika dilihat dari sumber pertumbuhan (source of growth), mesin pertumbuhan (engine of growth) yang menciptakan kinerja perekonomian tersebut adalah sektor primer dimana 16,60 persen dari 4,64 persen laju pertumbuhan tahun 2017 merupakan pertumbuhan nilai tambah (value added) di sektor pertambangan dan penggalian. Kondisi ini memperlihatkan ketergantungan perekonomian Provinsi Jambi pada sumber daya alam yang tidak dapat diperbaharui (Kurniawan, Budi. 2009).

Provinsi Jambi saat ini masih mengalami kekurangan di bidang infrastruktur yang dapat menghambat pembangunan yang dilakukan di Provinsi Jambi. Untuk membangun infrastruktur harus memiliki dana yang cukup besar. Sedangkan belanja modal Provinsi Jambi masih cukup kecil. Dari sisi sumber daya manusia juga masih jauh ketinggalan, lulusan pendidikan tinggi yang dibutuhkan untuk membidangi infrastruktur masih terbatas. Lulusan bidang teknis yang terbatas mengakibatkan 5 sampai 10 tahun ke depan Provinsi Jambi belum bisa maju bidang infrastrukturnya. Maka dengan alokasi belanja daerah yang ada diharapkan akan terjadi peningkatan Indeks Pembangunan Manusia di wilayah Provinsi Jambi.

Secara persentase kenaikan IPM kabupaten/kota di Provinsi Jambi dari tahun 20122018 adalah Provinsi Jambi naik 5,54\%, Kabupaten Kerinci naik 5,82\%, Kabupaten Merangin naik 5,36\%, Kabupaten Sarolangun naik 4,91\%, Kabupaten Batanghari naik 3,52\%, Kabupaten Muaro Jambi 6,50\%, Kabupaten Tanjung Jabung Timur 8,00\%, Kabupaten Tanjung Jabung Barat naik 6,79\%, Kabupaten Tebo naik 5,27\%, Kabupaten Bungo naik 3,30\%, Kota Jambi naik 4,92\% dan Kota Sungai Penuh naik 4,83\%. Berdasarkan data IPM kabupaten/kota di Provinsi Jambi didapatkan bahwa seluruh daerah di provinsi tersebut mengalami rata-rata peningkatan IPM dengan nilai yang bervariasi. Perbedaan tersebut dapat dipengaruhi oleh beberapa faktor diantaranya adalah, Rasio Guru dan Murid, Jumlah Sarana Kesehatan, Kepadatan Penduduk dan Kemiskinan (BPS Provinsi Jambi, 2018).

Selain fungsi pendidikan dan kesehatan, fungsi infrastruktur tidak kalah pentingnya, infrastruktur merupakan suatu sarana fisik pendukung agar pembangunan ekonomi suatu negara dapat terwujud. Infrastruktur terdiri dari beberapa sub sektor, beberapa diantaranya yang cukup dominan dalam pembangunan ekonomi adalah perumahan dan transportasi. Infrastruktur juga menunjukkan seberapa besar pemerataan pembangunan terjadi. Pemerintah sebagai pelaksana pembangunan tentunya membutuhkan modal manusia yang berkualitas sebagai modal dasar pembangunan. Untuk menghasilkan manusia yang berkualitas juga diperlukan upaya-upaya dalam 
meningkatkan kualitas sumber daya manusianya (Setiawan, 2006). Infrastruktur yang baik adalah pendukung yang sangat penting dalam tiap aktivitas agar berlangsung efektif dan efisien. Pembangunan akan tercapai jika didukung oleh infrastruktur yang memadai yang diindikasikan dengan kualitas layanan sarana dan prasarana yang baik (Indratno, 2008).

Belanja infrastruktur kabupaten/kota di Provinsi Jambi terus mengalami fluktuasi selama periode 2012-2018, Kabupaten Batanghari dari Rp. 129.271 juta menjadi Rp. 132.830 juta, Kabupaten Bungo dari Rp. 78.253 juta menjadi Rp. 200.143 juta, Kabupaten Kerinci dari Rp. 137.465 juta menjadi Rp. 135.370 juta, Kabupaten Merangin dari Rp. 175.666 juta menjadi Rp. 175.456 juta, Kabupaten Muaro Jambi dari Rp. 179.771 juta menjadi Rp. 250.362 juta, Kabupaten Sarolangun dari Rp. 131.660 juta menjadi Rp. 202.618 juta, Kabupaten Tanjung Jabung Barat dari Rp. 209.261 juta menjadi Rp. 359.825 juta, Kabupaten Tanjung Jabung Timur dari Rp. 233.725 juta menjadi Rp. 274.996 juta, Kabupaten Tebo dari Rp. 152.162 juta menjadi Rp. 212.909 Juta, Kota Jambi dari Rp. 118.722 juta menjadi Rp. 354.235 juta dan Kota Sungai Penuh dari Rp. 102.522 juta menjadi Rp. 171.114 juta.

Pertumbuhan ekonomi adalah perkembangan kegiatan dalam perekonomian yang menyebabkan barang dan jasa yang diproduksi bertambah. Akan tetapi, pertumbuhan ekonomi masih bersifat umum dan belum mencerminkan kemampuan masyarakat secara individual. Pertumbuhan ekonomi merupakan prasyarat bagi tercapainya pembangunan manusia, karena pertumbuhan ekonomi dapat meningkatkan produktivitas dan meningkatkan pendapatan. Sehingga pembangunan infrastruktur tidak bisa diabaikan karena merupakan faktor utama dalam peningkatan produktivitas.

Pertumbuhan ekonomi kabupaten/kota di Provinsi Jambi selama tahun 2012 sampai tahun 2018 yang digambarkan dalam persen. Pertumbuhan ekonomi Kabupaten Kerinci untuk tahun 2018 sebesar 5,1\%, Kabupaten Merangin sebesar 5,17\%, Kabupaten Sarolangun 4,72\%, Kabupaten Batanghari 4,96\%, Kabupaten Muaro Jambi 5,27\%, Kabupaten Tanjung Jabung Timur 3,13\%, Kabupaten Tanjung Jabung Barat 6,89\%, Kabupaten Tebo 5,02\%, Kabupaten Bungo 4,72\%, Kota Jambi 5,48\% dan Kota Sungai Penuhsebesar 5,54\%. Sementara pertumbuhan ekonomi Provinsi Jambi tahun 2018 hanya sebesar 4,71\% (BPS Provinsi Jambi, 2019).

Berdasarkan latar belakang tersebut, maka analisis mengenai faktor-faktor yang menentukan Indeks Pembangunan Manusia (IPM) menjadi penting karena hal ini secara tidak langsung mempengaruhi angka IPM. Sehingga membuat peneliti tertarik untuk menganalisis dan meneliti serta menuangkan ke dalam sebuah penelitian dengan Judul "Faktor penentu indeks pembangunan manusia dan hubungannya dengan belanja infrastruktur serta pertumbuhan ekonomi Kabupaten/ Kota di Provinsi Jambi”.

\section{METODE}

\section{Metode penelitian}

Metode penelitian yang digunakan dalam penelitian ini adalah metode analisis data sekunder berupa data deret waktu (time series data) selama kurun waktu tahun 20122018 dan data deret lintang (cross section) yang meliputi 11 (sebelas) kabupaten/kota di Provinsi Jambi. Metode analisis data sekunder adalah suatu metode dalam menganalisis suatu permasalahan atau fenomena dengan menggunakan data yang telah dikumpulkan, diolah, disajikan dan dilaporkan oleh pihak lain. Metode pengumpulan data sekunder sering disebut dengan penggunaan bahan dokumen. Dalam hal ini peneliti tidak langsung melakukan penelitian sendiri tetapi meneliti dan memanfaatkan data yang telah dihasilkan oleh pihak lain. 
Metode analisis dalam penelitian ini adalah metode deskriptif dengan pendekatan kualitatif dan kuantitatif. Analisis kualitatif digunakan untuk menggambarkan dan menguraikan keadaan persoalan yang didukung oleh fakta, sifatsifat serta hubungan antara fenomena yang dianalisis, sementara analisis kuantitatif digunakan untuk mengolah data menggunakan regresi berganda data panel.

\section{Model analisis pertama}

Dalam menjawab perumusan masalah pertama maka metode yang digunakan adalah analisis regresi berganda data panel dengan alat analisis menggunakan Eviews 10. Menurut Gujarati (2004), Data Panel (Longitudinal Data) adalah data yang memiliki dimensi ruang (individu) dan waktu. Dalam data panel, data cross section yang sama diobservasi menurut waktu. Jika setiap unit cross section memiliki jumlah observasi time series yang sama maka disebut sebagai Balanced Panel (total jumlah observasi $=\mathrm{N} x \mathrm{~T}$ ). Sebaliknya jika jumlah obeservasi berbeda untuk setiap unit cross section disebut Unbalanced Panel. Penggabungan data cross section dan time series dalam studi data panel digunakan untuk mengatasi kelemahan dan menjawab pertanyaan yang tidak dapat dijawab oleh model cross section dan time series murni. Dalam memastikan bahwa model yang diperoleh merupakan model yang tepat, maka sebelumnya akan dilakukan Uji Asumsi Klasik yang terdiri atas Uji Normalitas, Uji Multikolineritas, Uji Heteroskedastisitas dan Uji Autokorelasi untuk masing-masing model penelitian. Estimasi model menggunakan data panel dapat dilakukan dengan tiga metode, yaitu Metode Kuadrat Terkecil (Pooled Least Square), Metode Efek Tetap (Fixed Effect) dan Metode Efek Random (Random Effect).

Untuk menguji kesesuaian atau kebaikan model dari ketiga metode pada teknik estimasi model dengan data panel digunakan Chow Test dan Hausman Test. Chow Test digunakan untuk menguji kesesuaian model antara model yang diperoleh dari data Pooled Least Square dengan model yang diperoleh dari metode Fixed Effect. Selajutnya dilakukan Hausman Test terhadap model yang terbaik yang diperoleh dari hasil Chow Test dengan model yang diperoleh dari metode Random Effect.

Model analisis pertama merupakan alat analisis yang digunakan untuk melihat sejauh mana pengaruh variabel bebas Ratio Guru dan Murid $\left(\mathrm{RGM}_{1}\right)$, Jumlah Sarana Kesehatan $\left(\mathrm{JSK}_{2}\right)$, Kepadatan Penduduk $\left(\mathrm{KP}_{3}\right)$, dan Kemiskinan $\left(\mathrm{MKS}_{4}\right)$ terhadap variabel terikat Indeks Pembangunan Manusia kabupaten/kota Provinsi Jambi periode 2012-2018 (IPM).

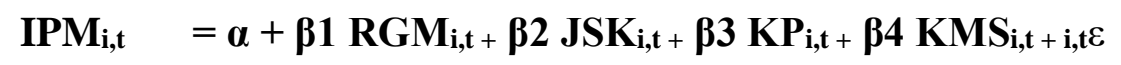

Dimana :

$\begin{array}{ll}\mathrm{IPM}_{\mathrm{i}, \mathrm{t}} & =\text { Indeks Pembangunan Manusia kabupaten/kota i pada tahun } \mathrm{t} \\ \mathrm{RGM}_{\mathrm{i}, \mathrm{t}} & =\text { Ratio Guru dan Murid kabupaten/kota i pada tahun } \mathrm{t} \\ \mathrm{JSK}_{\mathrm{i}, \mathrm{t}} & =\text { Jumlah Sarana Kesehatan kabupaten/kota } \mathrm{i} \text { pada tahun } \mathrm{t} \\ \mathrm{KP}_{\mathrm{i}, \mathrm{t}} & =\text { Kepadatan Penduduk kabupaten/kota i pada tahun } \mathrm{t} \\ \mathrm{KMS}_{\mathrm{i}, \mathrm{t}} & =\text { Persentase Kemiskinan kabupaten/kota } \mathrm{i} \text { pada tahun } \mathrm{t} \\ \alpha & =\text { Konstanta } \\ \beta 1, \beta 2, \beta 3, \beta 4 & =\text { Koefisien masing- masing variabel } \\ \varepsilon & =\text { Kesalahan Pengganggu (stokastik) } \\ \mathrm{i} & =\text { Data Cross Section yaitu } 11 \text { kabupaten/kota di Provinsi Jambi } \\ \mathrm{t} & =\text { Data Time Series dari tahun } 2012 \text { sampai tahun } 2017\end{array}$

\section{Model Analisis Kedua}

Untuk menjawab permasalahan dan tujuan penelitian kedua menggunakan analisis korelasi sederhana. Analisa yang membahas kuatnya hubungan antara variabel-variabel 
disebut “Analisa Korelasi”, sedangkan angka yang menunjukkan kuat tidaknya (derajat) hubungan antara variabel-variabel itu disebut dengan "Koefisien Korelasi" yang diberi notasi " $r$ ". Apabila arah hubungan variabel itu positif, disebut korelasi positif dan dua variabel itu cenderung akan berubah dengan arah yang sama. Apabila arah hubungan variabel itu negatif maka disebut korelasi negatif dan dua variabel itu cenderung akan berubah dengan arah yang berlawanan. Tetapi jika kedua variabel itu cenderung berubah dengan arah yang tidak menentu, maka dikatakan tidak berhubungan. Besarnya harga koefisien korelasi akan berada dalam interval -1 dan +1 atau $-1<\mathrm{r}<1$, artinya: 1 ). Jika $\mathrm{r}$ $=1$ atau mendekati, dikatakan bahwa dua variabel itu mempunyai hubungan yang kuat dan positif. 2).Jika $r=-1$ atau mendekati, dikatakan bahwa dua variabel itu mempunyai hubungan yang kuat dan negatif. 3).Jika $r=0$ atau mendekati, dikatakan bahwa dua variabel itu tidak berkorelasi atau berhubungan.

Rumus korelasi sederhana adalah sebagai berikut:

Dimana:

$$
r=\frac{n \varepsilon x y-(\varepsilon x)(\varepsilon y)}{\sqrt{\left\{n \epsilon x^{2}-(\varepsilon x)^{2}\right\}\left\{n \varepsilon y^{2}-(\varepsilon y)^{2}\right\}}}
$$

$\mathrm{r}=$ Koefisien korelasi $\mathrm{r}$ pearson

$\mathrm{n}=$ Jumlah sampel/observasi

$\mathrm{x}=$ Variabel IPM

$\mathrm{y}=$ Variabel belanja infrastruktur

Dilanjutkan dengan melakukan Uji Asumsi Korelasi seperti: 1).Normalitas. Artinya, sebaran variabel-variabel yang hendak dikorelasikan harus terdistribusi normal. 2).Liniearitas. Artinya, hubungan antara dua variabel harus linier. Misalnya ditunjukkan lewat Straingt-line. 3).Ordinal. Artinya, variabel harus diukur dengan minimal skala ordinal. 4).Homoskedastisitas. Artinya, variabilitas skor di variabel Y harus tetap konstan di semua nilai variabel $X$. Adapun variabel yang akan dibahas pada penelitian ini adalah Indeks Pembangunan Manusia (IPM) sebagai X dan Belanja Infrastruktur sebagai Y.

\section{Model analisa ketiga}

Untuk menjawab permasalahan dan tujuan penelitian ketiga menggunakan analisis korelasi sederhana. Analisa yang membahas kuatnya hubungan antara variabelvariabel disebut "Analisa Korelasi", sedangkan angka yang menunjukkan kuat tidaknya (derajat) hubungan antara variabel-variabel itu disebut dengan "koefisien korelasi" yang diberi notasi " $r$ ". Apabila arah hubungan variabel itu positif, disebut korelasi positif dan dua variabel itu cenderung akan berubah dengan arah yang sama. Apabila arah hubungan variabel itu negatif maka disebut korelasi negatif dan dua variabel itu cenderung akan berubah dengan arah yang berlawanan. Tetapi jika kedua variabel itu cenderung berubah dengan arah yang tidak menentu, maka dikatakan tidak berhubungan.

Besarnya harga koefisien korelasi akan berada dalam interval -1 dan +1 atau $-1<$ $\mathrm{r}<1$, artinya : 1).Jika $\mathrm{r}=1$ atau mendekati, dikatakan bahwa dua variabel itu mempunyai hubungan yang kuat dan positif. 2).Jika $r=-1$ atau mendekati, dikatakan bahwa dua variabel itu mempunyai hubungan yang kuat dan negatif. 3).Jika $r=0$ atau mendekati, dikatakan bahwa dua variabel itu tidak berkorelasi atau berhubungan.

Rumus korelasi sederhana adalah sebagai berikut: 


$$
r=\frac{n \varepsilon x y-(\varepsilon x)(\varepsilon y)}{\sqrt{\left\{n \epsilon x^{2}-(\varepsilon x)^{2}\right\}\left\{n \varepsilon y^{2}-(\varepsilon y)^{2}\right\}}}
$$

Dimana :

$\mathrm{r}=$ Koefisien korelasi $\mathrm{r}$ pearson

$\mathrm{n}=$ Jumlah sampel/observasi

$\mathrm{x}=$ Variabel belanja infrastruktur

$\mathrm{y}=$ Variabel pertumbuhan ekonomi

Dilanjutkan dengan melakukan uji asumsi korelasi seperti : 1).Normalitas. Artinya, sebaran variabel-variabel yang hendak dikorelasikan harus berdistribusi normal. 2).Liniearitas. Artinya, hubungan antara dua variabel harus linier. Misalnya ditunjukkan lewat Straingt-line. 3).Ordinal. Artinya, variabel harus diukur dengan minimal skala ordinal. 4).Homoskedastisitas. Artinya, variabilitas skor di variabel Y harus tetap konstan di semua nilai variabel $X$. Dalam penelitian ini variabel yang akan diteliti adalah Belanja Infrastruktur (X) dan Pertumbuhan Ekonomi (Y).

\section{HASIL DAN PEMBAHASAN}

\section{Faktor-faktor yang menentukan indeks pembangunan manusia}

Dalam memastikan bahwa model yang diperoleh merupakan model yang tepat, maka sebelumnya akan dilakukan Uji Asumsi Klasik yang terdiri atas Uji Normalitas, Uji Multikolineritas, Uji Heteroskedastisitas dan Uji Autokorelasi untuk masing-masing model penelitian.

\section{Uji normalitas}

Uji Normalitas yang digunakan dalam penelitian ini adalah menggunakan Uji Jarque Bera dengan melihat nilai probability. Jika nilai probability lebih besar dari nilai derajat kesalahan $\alpha=5 \%(0.05)$, maka penelitian ini tidak ada permasalahan normalitas atau dengan kata lain data terdistribusi normal, dan sebaliknya, jika nilai probability lebih kecil dari nilai derajat kesalahan $\alpha=5 \%(0,05)$, maka dalam penelitian ada permasalahan normalitas atau data tidak terdistribusi dengan normal. Maka terlihat hasilnya sebagai berikut:

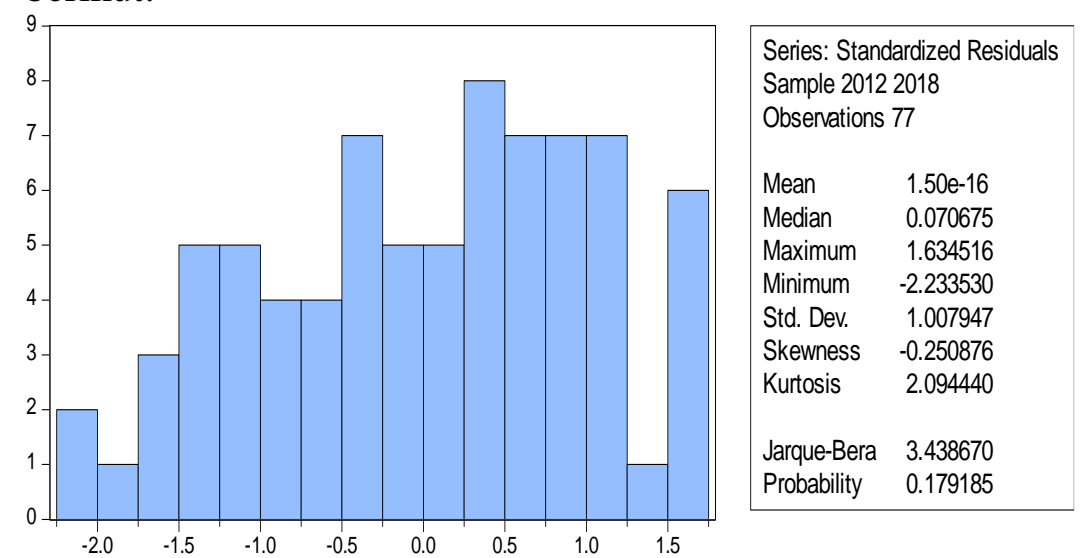

Gambar 1. Uji normalitas

Berdasarkan Gambar 1. uji normalitas menggambarkan bahwa data dalam penelitian ini sudah terdistribusi normal. Terlihat dari nilai probability sebesar 0,179185 lebih besar dari derajat kesalahan 5\% $(0,05)$, sehingga model ini dikatakan telah normal, dan bisa dilanjutkan ke pengujian selanjutnya. 


\section{Uji multikolinearitas}

Uji Multikolinieritas dilakukan untuk mengetahui ada tidaknya hubungan (korelasi) yang signifikan di antara dua atau lebih variabel independen dalam model regresi. Deteksi adanya multikolinieritas dilakukan dengan menggunakan Uji Korelasi Parsial antar variabel independen, kemudian dapat diputuskan apakah data terkena multikolinieritas atau tidak, yaitu dengan menguji koefisien korelasi antar variabel independen. Apabila nilai korelasi antar variabel lebih besar dari 0,8 maka dapat disimpulkan terdapat masalah multikolinieritas dalam model. Sedangkan, bila nilainya kurang dari 0,8 maka model tidak mengandung masalah multikolinieritas.

Tabel 1. Uji multikolinearitas

\begin{tabular}{ccccc}
\hline & RGM & JSK & KP & KMS \\
\hline RGM & 1.000000 & 0.614415 & 0.510608 & 0.206347 \\
JSK & 0.614415 & 1.000000 & 0.364304 & 0.426417 \\
KP & 0.510608 & 0.364304 & 1.000000 & 0.048475 \\
\hline KMS & 0.206347 & 0.426417 & 0.048475 & 1.000000 \\
\hline
\end{tabular}

Sumber : Data diolah, 2020

Berdasarkan Tabel 1 di atas dapat terlihat bahwa pengujian multikolinearitas dengan menggunakan correlation matrix, menghasilkan bahwa model ini tidak terdapat multikolinearitas. Karena nilai koefisien korelasi dari masing-masing variabel independen berada dibawah 0,8 sehingga dapat dilanjutkan ke pengujian selanjutnya yaitu Uji Heteroskedastisitas.

\section{Uji heterokedastisitas}

Uji Heteroskedastisitas ini dilakukan untuk mengetahui apakah dalam model regresi terjadi ketidaksamaan varian dari residual satu pengamatan ke pengamatan yang lain. Jika varian dari residual satu pengamatan ke pengamatan yang lain tetap, maka disebut Homoskedastisitas dan jika varian tidak konstan atau berubah-ubah disebut dengan Heteroskedastisitas. Uji Heterokedastisitas dilakukan dengan meregresi variabel independen terhadap residualnya. Hasil uji tersebut adalah sebagai berikut:

Tabel 2. Uji heterokedastisitas

\begin{tabular}{cc}
\hline Variable & Prob. \\
\hline C & 0.2328 \\
RGM & 0.6207 \\
JSK & 0.8270 \\
KP & 0.0980 \\
KMS & 0.1758 \\
\hline
\end{tabular}

Sumber: Data diolah, 2020

Dari Tabel 2 di atas, menunjukan bahwa nilai probabilitas untuk masing-masing model variabel independen terhadap residualnya. Oleh karena nilai probabilitas yang diperoleh lebih besar dari $\alpha=5 \%(0,05)$ maka tidak terdapat permasalahan heterokedastisitas. Hal ini memberikan putusan tidak terdapat masalah heteroskedastisitas dalam model.

\section{Uji autokorelasi}

Uji autokorelasi didefinisikan sebagai korelasi/keterkaitan antara serangkaian observasi yang diurutkan menurut ruang dan waktu. Untuk mengetahui ada atau tidaknya 
gejala autokorelasi dalam perhitungan regresi penelitian ini maka digunakan DurbinWatson Test sebesar 1,5424.

Dengan menggunakan tabel statistik Durbin-Watson pada derajat kepercayaan $95 \%(\alpha=0,05)$ dan jumlah observasi 77 serta jumlah variabel bebas 4 maka diperoleh angka $\mathrm{dl}=1,5228$ dan $\mathrm{du}=1,7407$ sedangkan nilai untuk 4-dl $=2,4772$ dan 4-du = 2,2593 dengan menggunakan Uji Statistik Durbin Watson Dua Ujung (two tailed) maka ketentuan yang digunakan adalah sebagai berikut : a).Jika $\mathrm{d}<\mathrm{dl}$, berarti terdapat autokorelasi positif. b).Jika d > du, berarti tidak terdapat autokorelasi positif. c).Jika (4-< dl, berarti terdapat autokorelasi negatif. d).Jika (4-d) $>$ du, berarti tidak terdapat autokorelasi negatif. e).Jika du $<\mathrm{d}<(4-$ du $)$, berarti tidak terdapat autokorelasi.

Berdasarkan ketentuan di atas didapatkan hasil nilai DW observasi terletak pada daerah (4-d) $>$ du atau tidak terdapat autokorelasi negatif dalam model pertama.

Dalam menestimasi metode regresi data panel terdapat metode yang biasa digunakan yaitu Metode Kuadrat Terkecil (Pooled Least Square), Metode Efek Tetap (Fixed Effect) dan Metode Efek Random (Random Effect). Untuk menguji kesesuaian atau kebaikan model dari ketiga metode pada teknik estimasi model dengan data panel digunakan Chow Test dan Hausman Test. Chow Test digunakan untuk menguji kesesuaian model antara model yang diperoleh dari data Pooled Least Square dengan model yang diperoleh dari metode Fixed Effect. Selajutnya dilakukan Hausman Test terhadap model yang terbaik yang diperoleh dari hasil Chow Test dengan model yang diperoleh dari metode Random Effect.

\section{Uji Chow test}

Chow-test dilakukan untuk mengetahui apakah sebaiknya menggunakan model Common Effect atau Fixed Effect. Hasil yang diperoleh dari perhitungan Chow-Test yang dilakukan dengan menggunakan Eviews 08 adalah sebagai berikut:

Tabel 3. Uji Chow test

\begin{tabular}{lrrr}
\hline Effects Test & Statistic & d.f. & Prob. \\
\hline Cross-section F & 18.884005 & $(10,62)$ & 0.0000 \\
Cross-section Chi-square & 107.621444 & 10 & 0.0000 \\
\hline
\end{tabular}

Sumber: Data diolah, 2020

Berdasarkan Tabel 3 terlihat bahwa F maupun Cross-section Chi-square adalah $0,0000<0,05$. Dengan demikian dapat dikatakan bahwa p-value $<\alpha$ yaitu dengan menggunakan tingkat $\alpha=5 \%(0,05)$. Hal ini artinya pendekatan estimasi model yang layak digunakan adalah Fixed Effect sehingga langkah selanjutnya yang harus diambil adalah melakukan Hausman-Test.

\section{Uji hausman test}

Hausman-Test digunakan untuk mengetahui apakah sebaiknya menggunakan model Fixed Effect atau Random Effect. Hasil yang diperoleh dari perhitungan HausmanTest yang dilakukan dengan menggunakan software Eviews 8 adalah sebagai berikut:

Tabel 4. Uji Hausman test

\begin{tabular}{|c|c|c|c|}
\hline Test Summary & $\begin{array}{l}\text { Chi-Sq. } \\
\text { Statistic }\end{array}$ & Chi-Sq. d.f. & Prob. \\
\hline Cross-section random & 16.407695 & 4 & 0.0025 \\
\hline
\end{tabular}

Sumber: Data diolah, 2020 
Berdasarkan tabel di atas dapat dilihat bahwa hasil dari Hausman-Test menujukkan nilai chi-square statistic sebesar 16,407695 > chi-square sebesar 1 dan nilai probabilitas Cross-section random adalah 0,0025 < 0,05. Dengan demikian dapat dikatakan bahwa pvalue $<\alpha$ yaitu dengan menggunakan tingkat $\alpha=5 \%(0,05)$. Dengan demikian dapat disimpulkan bahwa dengan menggunakan tingkat $\alpha 5 \%$ berarti model yang digunakan adalah model Fixed Effect. Berdasarkan hasil pengujian analisis model terbaik, ditemukan model yang akan digunakan untuk analisis lanjutan adalah model Fixed Effect (FE).

\section{Hasil uji hipotesis}

Pemilihan model yang telah dilakukan maka model Fixed Effect terpilih menjadi model terbaik untuk mengestimasi.

Tabel 5. Hasil uji regresi

\begin{tabular}{|c|c|c|}
\hline Variabel & t statistic & $\begin{array}{l}\text { p-val (Taraf } \\
\text { signifikansi) }\end{array}$ \\
\hline $\mathrm{RGM}_{1 \mathrm{it}}$ & 2,136776 & 0,0366 \\
\hline $\mathrm{JSK}_{2 \mathrm{it}}$ & 2,523653 & 0,0142 \\
\hline $\mathrm{KP}_{3 \mathrm{it}}$ & 2,010880 & 0,0487 \\
\hline $\mathrm{KMS}_{4 \mathrm{it}}$ & $-1,201630$ & 0,2341 \\
\hline
\end{tabular}

Variabel Depedent: $\mathrm{IPM}_{\mathrm{y}}$

$\begin{array}{ll}\text { R-Squared } & =0,9312 \\ \text { F-Statistic } & =59,952 \\ \text { Prob } & =0,0000\end{array}$

Sumber: Data diolah, 2020

Berdasarkan perhitungan dengan menggunakan E-views 10 diperoleh nilai-nilai koefesien regresi, dapat dibentuk suatu persamaan regresi sebagai berikut:

$$
I P M_{y}=\mathbf{4 1 , 4 0 7}+\mathbf{0 , 2 9 1} R G M_{1_{i t}}+\mathbf{3 , 5 4 7} J S K_{2_{i t}}+\mathbf{0 , 0 1 4} K P_{3_{i t}}-\mathbf{0 , 3 6 3} K M S_{4_{i t}}
$$

\section{Pegaruh silmultan (Uji F)}

Pada tabel 5 dapat dilihat bahwa dari hasil pengujian diperoleh nilai $\mathrm{F}$ sebesar 59,952 dan nilai prob F-test sebesar 0,000. Oleh karena nilai prob F-test lebih kecil dari 0,05 maka hipotesis diterima $\left(\mathrm{H}_{0}\right.$ ditolak dan $\mathrm{H}_{1}$ diterima). Artinya ratio guru dan murid, jumlah sarana kesehatan, kepadatan penduduk dan kemiskinan secara bersama-sama berpengaruh signifikan terhadap indeks pembangunan manusia.

\section{Pengaruh parsial (Uji t)}

Secara parsial, Ratio Guru dan Murid $\left(R G M_{1_{i t}}\right)$ berpengaruh positif dan signifikan terhadap Indeks Pembangunan Manusia $\left(\mathrm{IPM}_{\mathrm{y}}\right)$. Hal ini dibuktikan dengan nilai t sebesar 2,136 dengan taraf signifikansi 0,036. Oleh karena nilai t hitung lebih besar dari t tabel $(2,136>1,993)$ atau nilai signifikansi lebih kecil dari pada alpha 5\% $(0,036<$ 0,05). Dapat disimpulkan bahwa $\mathrm{H}_{1}$ diterima, artinya Ratio Guru dan Murid $\left(R G M_{1_{i t}}\right)$ berpengaruh terhadap Indeks Pembangunan Manusia $\left(\operatorname{IPM}_{\mathrm{y}}\right)$. Jadi, hipotesis yang menyatakan ratio guru dan murid berpengaruh signifikan terhadap indeks pembangunan manusia diterima. 
Secara parsial, Jumlah Sarana Kesehatan $\left(J S K_{2_{i t}}\right)$ berpengaruh positif dan signifikan terhadap Indeks Pembangunan Manusia $\left(\mathrm{IPM}_{\mathrm{y}}\right)$. Hal ini dibuktikan dengan nilai t sebesar 2,523 dengan taraf signifikansi 0,014. Oleh karena nilai t hitung lebih besar dari $t$ tabel $(2,523>1,993)$ atau nilai signifikansi lebih kecil dari pada alpha $5 \%(0,014<$ 0,05). Dapat disimpulkan bahwa $\mathrm{H}_{1}$ diterima, artinya Jumlah Sarana Kesehatan $\left(J S K_{2_{i t}}\right)$ berpengaruh terhadap Indeks Pembangunan Manusia $\left(\operatorname{IPM}_{\mathrm{y}}\right)$. Jadi, hipotesis yang menyatakan jumlah sarana kesehatan berpengaruh signifikan terhadap indeks pembangunan manusia diterima.

Secara parsial, Kepadatan Penduduk $\left(K P_{3_{i t}}\right)$ berpengaruh positif dan signifikan terhadap Indeks Pembangunan Manusia (IPM $)$. Hal ini dibuktikan dengan nilai t sebesar 2,010 dengan taraf signifikansi 0,048. Oleh karena nilai t hitung lebih besar dari t tabel $(2,010>1,993)$ atau nilai signifikansi lebih kecil dari pada alpha $5 \%(0,048<0,05)$. Dapat disimpulkan bahwa $\mathrm{H}_{1}$ diterima, artinya Kepadatan Penduduk $\left(K P_{3_{i t}}\right)$ berpengaruh terhadap Indeks Pembangunan Manusia $\left(\mathrm{IPM}_{\mathrm{y}}\right)$. Jadi, hipotesis yang menyatakan kepadatan penduduk berpengaruh signifikan terhadap indeks pembangunan manusia diterima.

Secara parsial, kemiskinan $\left(K M S_{4_{i t}}\right)$ berpengaruh negatif namun tidak signifikan terhadap Indeks Pembangunan Manusia (IPM $)$. Hal ini dibuktikan dengan nilai t sebesar $-1,201$ dengan taraf signifikansi 0,234. Oleh karena nilai t hitung lebih kecil dari t tabel $(-1,201<1,993)$ atau nilai signifikansi lebih besar dari pada alpha $5 \%(0,234>0,05)$. Dapat disimpulkan bahwa $\mathrm{H}_{0}$ ditolak, artinya kemiskinan $\left(K M S_{4_{i t}}\right)$ tidak berpengaruh terhadap Indeks Pembangunan Manusia $\left(\mathrm{IPM}_{\mathrm{y}}\right)$. Jadi, hipotesis yang menyatakan kemiskinan berpengaruh signifikan terhadap indeks pembangunan manusia ditolak.

\section{Koefisien determinasi $\left(\mathbf{R}^{2}\right)$}

Koefisien determinasi berfungsi untuk melihat kemampuan variabel independent menerangkan variabel dependent dapat diketahui dari besarnya koefisien determinasi $\left(\mathrm{R}^{2}\right)$. Berdasarkan tabel 5 dapat diketahui pengaruh pada model regresi ini menunjukkan seberapa kuat pengaruh ratio guru dan murid, jumlah sarana kesehatan, kepadatan penduduk dan kemiskinan terhadap indeks pembangunan manusia secara keseluruhan. Hasil penelitian diperoleh angka koefisien determinasi $\mathrm{R}^{2}=0,9312$. Angka ini dapat diartikan bahwa tinggi rendahnya Indeks Pembangunan Manusia (IPM) disebabkan atau dipengaruhi oleh baik buruknya dari ratio guru dan murid, jumlah sarana kesehatan, kepadatan penduduk dan kemiskinan sebesar 93,12 persen. Sedangkan sisanya dipengaruhi oleh variabel lain yang tidak masuk dalam model regresi tersebut.

\section{Hubungan antara indeks pembangunan manusia dengan belanja infrastruktur Kabupaten/Kota di Provinsi Jambi}

Untuk mengetahui seberapa besar hubungan diantara kedua variabel tersebut maka digunakan alat analisis pearson correlation. Adapun hasil analisis korelasi antara indeks pembangunan manusia dengan belanja infrastruktur dapat dilihat pada tabel 6 berikut:

Tabel 6. Hasil analisis korelasi pearson model kedua

\begin{tabular}{llrr}
\hline & IPM & \multicolumn{1}{c}{ BINF } \\
\hline IPM & Pearson Correlation & 1 & -.131 \\
& Sig. (2-tailed) & & .255 \\
& N & 77 & 77 \\
BINF & Pearson Correlation & -.131 & 1 \\
& Sig. (2-tailed) & .255 & \\
& N & 77 & 77 \\
\hline
\end{tabular}

Sumber : Data diolah, 2020 
Berdasarkan Tabel 6 dapat dijelaskan nilai korelasi pearson antara Indeks Pembangunan Manusia (IPM) dengan Belanja Infrastruktur (BINF) memiliki nilai koefisien korelasi sebesar 0,131 dengan arah negatif dan tidak signifikan $(0,255>0,05)$. Koefisien bernilai negatif dan tidak signifikan artinya terjadi hubungan negatif antara belanja infrastruktur secara langsung terhadap IPM, dimana semakin naik nilai belanja infrastruktur maka akan semakin menurunkan nilai IPM atau nilai signifikansi lebih besar daripada alpha $5 \%$.

\section{Hubungan antara belanja infrastruktur dengan pertumbuhan ekonomi Kabupaten/Kota di Provinsi Jambi}

Untuk mengetahui seberapa besar hubungan diantara kedua variabel tersebut maka digunakan alat analisis pearson correlation. Adapun hasil analisis korelasi antara belanja infrastruktur dengan pertumbuhan ekonomi dapat dilihat pada tabel 7 berikut:

Tabel 7. Hasil analisis korelasi pearson model ketiga

\begin{tabular}{rlrr}
\hline & & BINF & \multicolumn{2}{c}{ PE } \\
\hline BINF & Pearson Correlation & 1 & $.476^{* *}$ \\
& Sig. (2-tailed) & & .000 \\
& N & 77 & 77 \\
PE & Pearson Correlation & $.476^{* * *}$ & 1 \\
& Sig. (2-tailed) & .000 & \\
& N & 77 & 77 \\
\hline
\end{tabular}

**. Correlation is significant at the 0.01 level (2-tailed).

Sumber : Data diolah, 2020

Berdasarkan Tabel 7 dapat dijelaskan nilai korelasi pearson antara belanja infrastruktur dengan pertumbuhan ekonomi memiliki nilai koefisien korelasi sebesar 0,476 searah positif dan signifikan $(0,000<0,05)$. Koefisien bernilai positif dan signifikan artinya terjadi hubungan positif antara belanja infrastruktur secara langsung terhadap pertumbuhan ekonomi, dimana semakin naik nilai belanja infrastruktur maka akan semakin menaikan nilai pertumbuhan ekonomi atau nilai signifikansi lebih kecil daripada alpha 5\%. Nilai korelasi ini mengindikasikan bahwa hubungan antara perkembangan nilai belanja infrastruktur dan pertumbuhan ekonomi tergolong sedang ($1<0,476<1)$.

\section{Implikasi kebijakan}

Dari hasil penelitian diketahui variabel ratio guru terhadap murid berpengaruh secara positif dan signifikan terhadap indeks pembangunan manusia kabupaten/kota di Provinsi Jambi. Hasil ini tidak sejalan dengan penelitian yang dilakukan (Rubiyatno, 2012) yang menyatakan bahwa ratio guru terhadap murid tidak berpengaruh signifikan terhadap IPM di Indonesia. Tetapi sejalan dengan penelitian yang dilakukan oleh (Sangkereng. W, 2019) yang menemukan bahwa jumlah guru dan murid berpengaruh positif terhadap indeks pembangunan manusia. Dengan melihat hasil ini dapat diketahui bahwa pendidikan adalah hal yang sangat penting dan perlu diperhatikan oleh pemerintah kabupaten/kota di Provinsi Jambi. Dengan semakin meningkatnya mutu pendidikan, maka kualitas hidup seseorang akan meningkat dalam menjalani hidup karena dengan mendapatkan pendidikan yang layak, seseorang akan mempunyai pengetahuan, keterampilan, dan wawasan yang lebih dibandingkan dengan orang yang tidak mendapatkan pendidikan. Untuk itu pengeluaran pemerintah untuk pendidikan sangat 
diperlukan untuk meningkatkan kualitas sumber daya manusia. Pemerintah kabupaten/kota Provinsi Jambi telah mencanangkan program wajib belajar 12 tahun, untuk memberikan pendidikan seluas-luasnya kepada penduduk. Secara formal, pemerintah kabupaten/kota Pronvinsi Jambi juga mengoptimalkan/mengasah keterampilan penduduk dengan mendorong anak-anak untuk bersekolah di sekolah kejuruan, dengan harapan setelah lulus sekolah siswa dapat memiliki keterampilan dan bersaing di dunia kerja bahkan mampu untuk menciptakan lapangan pekerjaan sendiri. Secara informal, pemerintah kabupaten/kota Pronvinsi Jambi melalui program kegiatan ekonomi produktif mendorong masyarakat untuk memiliki keterampilan seperti membatik, budidaya pertanian/perikanan, pengolahan bahan makanan, keterampilan anyaman dan tembikar, sehingga diharapkan akan meningkatkan kesejahteraan masyarakat sebagai tujuan utama pembangunan manusia yang telah diaplikasikan dalam IPM.

Dari hasil penelitian diketahui variabel jumlah sarana kesehatan berpengaruh secara positif dan signifikan terhadap indeks pembangunan manusia kabupaten/kota di Provinsi Jambi. Hasil ini memperkuat temuan dari Latuconsina (2017) dimana jumlah fasilitas kesehatan berpengaruh positif dan signifikan pada taraf nyata 5 persen terhadap IPM. Dalam kaitannya dengan jumlah sarana kesehatan tentu tidak terlepas daripada pengeluaran yang dilakukan pemerintah kabupaten/kota Provinsi Jambi. Hal tersebut dapat mengartikan bahwa pengeluaran pemerintah kabupaten/kota Provinsi Jambi telah efektif dalam membelanjakan beberapa alokasi bantuan kesehatan secara langsung maupun tidak langsung, baik berupa pembangunan sarana kesehatan maupun prasarana kesehatan lainnya. Implikasi dari temuan ini menekankan pentingnya meningkatkan akses dan mutu pelayanan kesehatan terhadap seluruh masyarakat agar tercapai derajat kesehatan masyarakat yang optimal secara efektif dan efisien.

Dari hasil penelitian diketahui variabel kepadatan penduduk berpengaruh secara positif dan signifikan terhadap indeks pembangunan manusia kabupaten/kota di Provinsi Jambi. Hal ini sejalan dengan penelitian dari Yudi Antara (2020) yang menemukan bahwa semakin banyak penduduk memusat di satu titik tertentu, maka keberadaan fasilitas publik semakin lengkap, begitu pula sebaliknya. Dengan demikian dapat dikatakan bahwa, kepadatan penduduk yang tinggi memiliki korelasi dengan ketersediaan fasilitas pelayanan publik, yang selanjutnya dari ketersediaan fasilitas tersebut pada akhirnya berpengaruh terhadap kualitas manusianya. Penduduk dalam jumlah yang besar merupakan modal dalam pembangunan ekonomi. Penduduk usia produktif yang termasuk dalam angkatan kerja merupakan tenaga kerja yang terserap di lapangan pekerjaan dan pendorong dalam menghasilkan output suatu wilayah (Tambunan, 2001). Kaitannya dengan indeks pembangunan manusia yaitu apabila indeks pembangunan manusia menunjukkan kondisi baik setidaknya banyak tenaga kerja yang terserap dalam lapangan pekerjaan dan berkurangnya jumlah pengangguran usia produktif. Oleh karena itu, pemerintah harus bisa mengoptimalkan potensi kepadatan penduduk yang sudah ada baik melalui program latihan kerja di Balai Latihan Kerja maupun penempatan tenaga kerja melalui pola kerjasama atau kemitraan yang pada akhirnya diharapkan dapat meningkatkan kesejahteraan masyarakat dan mengurangi kemiskinan.

Dari hasil penelitian diketahui variabel kemiskinan berpengaruh secara negatif namun tidak signifikan terhadap indeks pembangunan manusia kabupaten/kota di Provinsi Jambi. Artinya bila terjadi peningkatan kemiskinan maka indeks pembangunan manusia akan mengalami penurunan. Hasil ini sejalan dengan penelitian dari Kacaribu, R.A. (2013) yang menemukan bahwa tingkat kemiskinan berpengaruh negatif dan signifikan terhadap indeks pembangunan manusia di Provinsi Papua. Hal ini terjadi seiring dengan semakin meningkatnya penduduk dan berkembangnya wilayah. Peningkatan penduduk yang tidak dibarengi dengan peningkatan pelayanan kebutuhan 
dasar manusia dan upaya-upaya peningkatan daya beli akhirnya akan menyebabkan kemiskinan. Hal ini tentu menjadi bahan evaluasi untuk pemerintah kabupaten/kota agar bisa mengurangi tingkat kemiskinan. Misalnya melalui upaya program kegiatan ekonomi produktif, menjaga stabilitas harga bahan pokok, meningkatkan akses masyarakat miskin kepada pelayanan dasar dalam memenuhi kebutuhan pendidikan dan kesehatan. Selain itu, menciptakan lapangan kerja yang mampu menyerap banyak tenaga kerja sehingga mengurangi pengangguran, karena pengangguran merupakan salah satu sumber kemiskinan terbesar.

Hubungan antara indeks pembangunan manusia dengan belanja infrastruktur memiliki arah negatif dan tidak signifikan. Hasil studi ini sejalan dengan Badrudin (2011) yang juga menemukan bahwa belanja infrastruktur di Provinsi D.I. Yogyakarta ternyata berhubungan negatif terhadap IPM meski tidak terbukti signifikan. Hal ini menunjukkan pengelolaan belanja infrastruktur di pemerintah daerah kabupaten/kota Provinsi Jambi belum fokus untuk meningkatkan kesejahteraan masyarakat yang diproksikan dengan Indeks Pembangunan Manusia (IPM). Implikasi dari kajian ini adalah pemerintah daerah yang berorientasi menyejahterakan masyarakat hendaknya dapat mengelola aset dan belanja infrastruktur dengan baik. Usaha untuk meningkatkan aset daerah akan ikut juga meningkatkan nilai IPM. Peningkatan aset daerah ini diantaranya merupakan konsekuensi dari belanja infrastruktur yang dilakukan pemerintah daerah. Namun, kajian ini menunjukkan hubungan antar variabel tersebut tergolong tidak signifikan. Oleh karenanya, pengelolaan belanja infrastruktur hendaknya menjadi perhatian pemerintah daerah. Belanja infrastruktur untuk publik harus dialokasikan lebih besar daripada belanja infrastruktur untuk aparatur sehingga dapat tepat mengenai dimensi dasar IPM. Misalnya, alokasi belanja infrastruktur untuk pembangunan gedung sekolah sehingga pendidikan masyarakat meningkat dan tepat mengenai salah satu dimensi IPM yaitu dimensi pengetahuan agar ke depannya IPM kabupaten/kota Provinsi Jambi bukan hanya memiliki IPM yang tinggi tapi mampu meningkatkan kualitasnya lebih baik lagi.

Penelitian oleh Prasetyo dan Firdaus (2009) menyimpulkan bahwa pertumbuhan ekonomi Indonesia dipengaruhi oleh ketersediaan infrastruktur, di antaranya elektrifikasi, jalan beraspal, dan air bersih. Sejalan dengan penelitian tersebut, hasil penelitian menunjukkan bahwa hubungan antara belanja infrastruktur dengan pertumbuhan ekonomi di kabupaten/kota Provinsi Jambi tergolong sedang sehingga dibutuhkan beberapa langkah strategis yang harus dilakukan oleh pemerintah Provinsi Jambi umumnya dan pemerintah kabupaten/kota pada khususnya agar alokasi dana belanja infrastruktur ini efektif penggunaannya dengan tujuan untuk meningkatkan pertumbuhan ekonomi daerah. Ada beberapa hal yang harus menjadi catatan dan butuh evaluasi diantaranya: (1) Perlu adanya planning atau perencanaan yang matang terhadap belanja infrastruktur yang akan dianggarkan sehingga tidak hanya fokus pada pembangunan jalan dan jembatan atau bangunan fisik yang akhirnya tidak berfungsi. Belanja infrastruktur diharapkan akan dapat meningkatkan pertumbuhan ekonomi yang baik dan stabil, namun karena salah dalam hal perencanaan dan pemetaan awal akan menjadikan dana pembangunan yang sia-sia. (2) Melakukan pemetaan kembali terhadap usaha-usaha atau sektor-sektor yang memberikan kontribusi yang lebih terhadap pertumbuhan ekonomi sehingga lebih dioptimalkan serta diiringi dengan pengawasan terhadap stakeholder yang menerima dampak baik secara langsung maupun tidak langsung dari belanja infrastruktur tersebut. Apakah dampak tersebut memberikan efek peningkatan terhadap pertumbuhan ekonomi ataukah hanya menjadi bangunan yang tidak terpakai.

\section{KESIMPULAN DAN SARAN}

\section{Kesimpulan}

Faktor-faktor yang menentukan Indeks Pembangunan Manusia (IPM) kabupaten/kota di Provinsi Jambi, yaitu: ratio guru dan murid, jumlah sarana kesehatan, 
kepadatan penduduk, serta kemiskinan. Terhadap Indeks Pembangunan Manusia (IPM) kabupaten/kota di Provinsi Jambi selama periode 2012-2018 dapat disimpulkan ratio guru dan murid, jumlah sarana kesehatan, kepadatan penduduk, serta kemiskinan secara simultan berpengaruh dalam menentukan IPM kabupaten/kota di Provinsi Jambi. Sedangkan jika dilihat secara parsial, faktor ratio guru dan murid, jumlah sarana kesehatan, kepadatan penduduk memiliki pengaruh positif dan signifikan dalam menentukan IPM. Sedangkan faktor kemiskinan berpengaruh negatif tetapi tidak signifikan secara statistik dalam menentukan IPM kabupaten/kota di Provinsi Jambi.

Hubungan Indeks Pembangunan Manusia (IPM) dengan belanja infrastruktur menunjukkan bahwa indeks pembangunan manusia tidak mempunyai korelasi dengan belanja infrastruktur kabupaten/kota di Provinsi Jambi.

Hubungan belanja infrastruktur dengan pertumbuhan ekonomi menunjukkan bahwa belanja infrastruktur mempunyai korelasi positif yang tergolong sedang dengan pertumbuhan ekonomi kabupaten/kota di Provinsi Jambi.

\section{Saran}

Variabel ratio guru dan murid, jumlah sarana kesehatan serta kepadatan penduduk memiliki pengaruh positif dan signifikan terhadap Indeks Pembangunan Manusia (IPM) sehingga variabel tersebut perlu ditingkatkan setiap tahunnya. Kenaikan setiap variabel tersebut akan mempengaruhi kenaikan IPM jika pembangunan dilaksanakan secara inklusif yang diikuti oleh pemerataan kesejahteraan penduduk. Sementara variabel kemiskinan yang pengaruhnya negatif namun tidak signifikan secara statistik harus tetap diperhatikan mengingat pengentasan kemiskinan merupakan kunci kesejahteraan masyarakat dikarenakan kemiskinan yang tidak terkendali bisa mengakibatkan daerah tersebut lemah dari segi IPM dan juga akan berdampak langsung pada bidang ekonominya. Oleh karena itu, pemerintah terkait khususnya kabupaten/kota di Provinsi Jambi hendaknya dapat menaikkan pendapatan masyarakat sehingga dapat keluar dari jurang kemiskinan. Selain itu, untuk pengembangan penelitian ini lebih lanjut disarankan agar peneliti berikutnya dapat menambah variabel maupun tahun penelitian yang disesuaikan dengan kondisi kabupaten/kota di Provinsi Jambi.

Belanja infrastruktur memiliki pengaruh negatif dan secara statistik tidak signifikan. Faktor inefisiensi dan ketidaktepatan sasaran diduga menjadi salah satu penyebab munculnya pengaruh negatif terhadap belanja infrastuktur ini. Alokasi belanja yang besar tanpa disertai efisiensi tidak memberikan hasil pembangunan yang berkualitas, sehingga lebih baik anggaran didistribusikan pada sektor publik yang lebih efisien. Oleh karena itu, perlu adanya kajian terhadap efisiensi dan proporsi anggaran belanja infrastruktur karena berpotensi menurunkan nilai IPM.

Berdasarkan hasil penelitian diketahui bahwa peningkatan belanja infrastruktur kabupaten/kota di Provinsi Jambi memiliki korelasi positif dan signifikan terhadap peningkatan pertumbuhan ekonomi. Namun nilai korelasinya tergolong sedang artinya masih memberikan sedikit sekali pengaruh. Dengan demikian disarankan untuk para stakeholder kabupaten/kota di Provinsi Jambi agar memperbesar anggaran belanja bidang infrastruktur pada tahun-tahun yang akan datang untuk meningkatkan pertumbuhan ekonomi di kabupaten/kota di Provinsi Jambi.

\section{DAFTAR PUSTAKA}

Badan Pusat Statistik. (2015). Indeks pembangunan manusia 2014.diakses dalam http://www.bps.go.id, pada tanggal 20 November 2018, Pukul 8.00 WIB

Badan Pusat Statistik.(2018). Tabel indeks pembangunan manusia (Metode Baru).diakses dalam http://www.bps.go.id, pada tanggal 20 November 2018, Pukul 8.00 WIB 
Badan Pusat Statistik.(2019). Pertumbuhan ekonomi Provinsi Jambi. Diakses dalam http://www.bps.go.id, pada tanggal 20 November 2018, Pukul 8.00 WIB

Badan Pusat Statistik.(2019). Indeks pembangunan manusia Provinsi Jambi. diakses dalam dari http://www.bps.go.id, pada tanggal 20 November 2018, Pukul 8.00 WIB

Badrudin, Rudi.(2011). Pengaruh pendapatan dan belanja daerah terhadap pembangunan manusia di Provinsi Daerah Istimewa Yogyakarta, Buletin Ekonomi, Jurnal Manajemen, Akuntansi, dan Ekonomi Pembangunan, 9(1), 23-30

Gujarati, DN.(2004). Ekonometrika dasar. Erlangga: Jakarta.

Indratno, Imam.(2008). Indeks pembangunan desa sebagai ukuran keberhasilan pengembangan perdesaan. Universitas Islam Bandung: Bandung.

Kacaribu, Dewi, dkk.(2013). Analisis indeks pembangunan manusia dan faktor-faktor yang memengaruhi di provinsi papua [Tesis]. Sekolah Pascasarjana Institut Pertanian Bogor: Bogor.

Kurniawan, Budi.(2009). Dampak ketergantungan perekonomian provinsi jambi terhadap sumber daya alam tak terbarukan (pemberlakuan kuota eksporbatubara [Tesis].Departemen Ilmu Ekonomi Fakultas Ekonomi dan Manajemen IPB: Bogor.

Latuconsina, Zulfikar Mohamad Yamin. (2017). Analisis faktor-faktor yang mempengaruhi indeks pembangunan manusia Kabupaten Malang Berbasis Pendekatan Perwilayahan dan Regresi Panel. Journal of Regional and Rural Development Planning, 1(2), 202-216. https://doi.org/10.29244/jp2wd.2017. 1.2.202- 216

Made Yudi Antara, I gede dan I Gede Putu Eka Suryana. (2020). Pengaruh tingkat kepadatan penduduk terhadap indeks pembangunan manusia di Provinsi Bali. Fakultas Hukum dan Ilmu Sosial UNDIKSHA dan IGIaa: Bali.

Pemerintah Provinsi Jambi. (2017). Laporan keuangan pemerintah daerah Provinsi Jambi Tahun Anggaran 2016. Diakses dari http://jambiprov.go.id, Tanggal 20 November 2018, Pukul 18.00 WIB

Prasetyo, Firdaus, dkk. (2009). Pengaruh infrastruktur pada pertumbuhan ekonomi wilayah di Indonesia. Jurnal Ekonomi dan Kebijakan Pembangunan. Departemen Ilmu Ekonomi-Fakultas Ekonomi dan Manajemen-IPB: Bogor.

Rubiyatno. (2012). Hubungan status dan fasilitas pendidikan dengan pembangunan manusia. Jurnal Bisnis dan Ekonomi. 4(1), 64-77

Sangkereng, Windy. (2019). Faktor-faktor yang mempengaruhi indeks pembangunan manusia di Provinsi Sulawesi Utara. Jurnal Berkala Ilmiah Efisiensi, 19(4), 60-71

Setiawan, Muhammad Bhakti. (2006). Indeks pembangunan manusia Indonesia.Jurnal Economia, 9(1), 18-26

Tambunan, Tulus. (2001). Transformasi ekonomi di Indonesia. Salemba Empat: Jakarta.

UNDP. (2016). Indonesia, indeks pembangunan manusia. dari http://www.undp.or.id, diakses pada tanggal 22 November 2018, Pukul 18.00 WIB 